\title{
The Use of Digital Game-Based Learning in EFL Classroom: Teacher's voices
}

\author{
Taufik \\ Faculty of Education, \\ UIN Sunan Ampel Surabaya \\ Perisya Hilmun \\ Faculty of Education, \\ UIN Sunan Ampel Surabaya
}

\begin{abstract}
The use of digital technology and play based learning in English Language Teaching still become the most popular thing in this modernized era. It is inevitable for teacher nowadays to use brand new and fun technology in their teaching yet, many of them are unable to use it due to several reasons such as limited facilities and lack of ability. This paper provides a critical analysis on the EFL teachers' voice behind the use of educational technologies, including; digital games. A qualitative research sheds light on the teachers' discernment and preconceptions toward the use of digital games, strategy to implement it, and the challenges in the class. Structured, face-to-face interview sessions among high school teachers' and university lecturers' suggest that the use of digital game based learning in EFL classroom is quite common, but the limited facilities becomes the biggest challenge for this thing. The engagement with educational digital game is bringing new atmosphere, and improving students' critical thinking as it helps them make evaluative decisions to solve problems. At the same time, the results reveal that most of the students in the class can develop their interpersonal skills as they collaborate in teams and work in tandem with their peers, during their formative activities. However, there are also some teachers who are not perceiving the usefulness and the ease of use of using digital games at school. This study implies that practitioners in education ought to consider taking an iterative approach as they identify what, where, when and how digital games are (or are not) consistent with the courses' learning outcomes. In conclusion, this paper opens- up some avenues for future research in the more promising field of digital game-based learning.
\end{abstract}

Keywords: technology in education, digital games in EFL, digital game- based learning

\section{INTRODUCTION}

In the modernised era with the high growth of technology, the utilisation of Technology in EFL

\author{
Erika Nuris Sabella \\ Faculty of Education, \\ UIN Sunan Ampel Surabaya \\ Sabrina Sanda M \\ Faculty of Education, \\ UIN Sunan Ampel Surabaya
}

classroom becomes one of the most popular issues that is still commonly studied and discussed. The high development of technology has significantly changed people's perspective and becomes an option for education fields, e-learning, and strategy to develop a better education. As Chen (2016) states that a strategy of learning applying network delivery and extracting learning information could break through the efficient learning of knowledge and skills. One of the utilization of technology in the teaching and learning process is DGBL. Digital Game-based learning (DGBL) as it has come to be known, started out as an instructional strategy that can be embodied through both computer and mobile-based applications. (Jin, Tu, Kim, Heffron, \& White, 2018) indicated that what is called by game based learning is the learning process that engaged game application in the real classroom.

EFL Teachers across the globe, have considered Digital game-based learning as one of strategies to engage and motivate students ${ }^{2}$ and present learning experiences while helping long term memory and providing practical experience. Another benefit is when it's compared to traditional teaching strategies, DGBL can also offer learners an interactive learning experience and bolster independent learning (Lin \& Lan, 2015; Yukselturk, 2018). Moreover, Cam \& Tran (2017) also stated that DGBL enable students to connect learning content to their everyday life. Furthermore, a numerous study has specified the use of nontraditional interventions, such as games, simulations, multimedia instruction and interactive activities are valuable teaching methods. According to Feng's (2009) study, when used appropriately and frequently computer or mobile games may be a good self-study tool. They allow the student to practice the target language in an enjoyable environment, as well as on their own time. Feng (2009) continues to state that the games would enable learners to develop their automaticity in their L2.

On the other hand, Mohammad, Fayyoumi, \& AlShathry (2014) stated that there are some debatable issues among teachers concerning to the 
use of mobile or computer technologies in the classroom.4 They don't agree with the use of smartphones in the classroom because of some reasons while the other looked that there are some potential advantages of it. Some teachers also don't want to use digital game in the classroom with several reasons such as there are some school in the developing country such as Indonesia which still don't have good internet connection and no good technology provided, another reason is teachers do not master technological skill so they just feel lazy to use it. Nowadays, there are many digital games are available, free and easy to use. Another matter is, if the digital games cannot be easily utilized to the classroom which does not provide a quite good technology.

Knowing that many benefits and drawbacks, therefore this present study reveal Indonesian teachers' experience in implementing DGBL to boost teaching process. The second is tries to seek what will the teachers do in deciding the effective games in teaching and learning process and what challenge they face. Also, this study will try to reflect the solutions of the problems during the applying of the games in the middle of the learning's activity by the teachers and how the teacher cope it. The experiences of the teachers in using games in the teaching and learning process will give us what separated in between the results in implemented the games in teaching and learning or without the implementation of it or the lecturing using traditional methods that require the teacher keep in interact to the students without any kinds of special activities in the same terms of classes which consist of the students in the same level, which are the beginner learners.

\section{Research questions}

Based on the background of the research, the researcher conducts the main research question, stated as follows:

1. How is teachers' experiences in implementing DGBL in the EFL classroom?

2. What might be teachers' challenges in implementing DGBL?

3. How do teachers' deal with the challenges they might face?

\section{METHOD}

This research will use qualitative descriptive to find out the result of research question. Creswell (2008) argued that qualitative research means study which researcher trusts on the view of contributors like asks board, general questions, gather data from participants, defines and investigates for themes, and conduct the inquiry in a subjective, biased manner18. Researchers organised purposive, face-to-face interview meetings with the total of 6 participants in High School and University in Surabaya. The researcher obtained the participants' was committed to protect their confidentiality and anonymity. Therefore, this research project safeguarded the welfare of vulnerable participants. All informants were treated fairly and within an ethic of respect and freedom from prejudice. This research use linear snowball sampling (non-probability sampling) in which the samples have traits that are rare to find. This is a sampling technique, in which existing subjects provide referrals to recruit samples required for a research study. This sampling method involves a primary data source nominating other potential data sources that will be able to participate in the research studies because at the beginning of collecting the data, the researchers only found two participants.

\section{Participant and Setting}

Research subject in this research is someone who give the data for some questions provided by the researcher. The total number in this research are 6 participants. They are the teacher or lecturer who have already used digital game based in their classroom. Two of English teacher and four of English lecturer are selected to took part in this study. Two of the, were chosen from two different high schools in Surabaya and some lecturers in the state Islamic university of Sunan Ampel Surabaya, Indonesia. The participants were all selected due to their experience in using digital game for teaching, either they often use the digital games, or rarely use it.

\section{Data Collection Technique}

Because all of the data are gotten from the English teachers and lecturers, Interview was used as data collection technique. The researchers of this study collect the data based on both teachers and lecturer's experiences in using digital game based in their classroom. This is because the researcher need to get the deep and accurate data from the participants.

\section{Instruments}

This study primarily used interview guideline as the instrument to obtain qualitative data from the teachers, and it will automatically answer all the research questions. Cited from Khoirum Anam (2012), Suharsini Arikunto stated that Interview Guideline is the tool which help the teacher getting the data. Based on the data collection technique that is used in this research, Interview guideline and researcher are used as instrument of this research.

There were ten questions employed in this study which will be categorized into three categories to answer the research questions, including the implementation of Digital Game Based Learning in EFL classroom, The teacher's preliminary 
experience in Digital Game Based Learning in EFL classroom, The effectiveness of using Digital Game Based Learning in EFL classroom. The interview used not only to answer the main research questions but also to determine how teacher perceive teaching English by using Digital game based learning.

\section{Reseach Procedure}

Based on the research procedure and data collection technique, the data from the participants were collected by doing some interviews. This research has procedure that is classified onto three steps. They are preparation, research process, and analyzing the darta.

In the preparation, the researchers prepared all of the things to do the research later. They are include making questions to get the data from the participants, and making appointment with research subjects to do interview to get the data, it was done by asking permission to the participants whether it's about they are able or not and about the place also the time to do interview.

The next step is about research process. It was done by doing face-to face interview with the research subject. The researchers came to the research subject's place based on the appointment. The researchers did the interview by giving opening question. On the process of interview, the researchers wrote some important answer from the research subject and didn't forget to do recording also, it's to help the researchers when they forget about the answers from the research subject.

The last step is checking the data that have gained. It's to check the data that is needed by the researchers, whether it's complete or any missing data that haven't gained by the researchers.

\section{Data Analysis Technique}

The interview were held with the lecturers and teachers as the participants who teach in several schools and an university in Surabaya. The data would be analysed in Qualitative research ways. Specific approach of the way it would be analysed is by using phenomenological study, the study which investigates various reactions to, or perceptions of, a particular phenomenon20. Therefore, their views, impressions and opinions were annotated in reflective notes and recorded as the audio recording. As explained, we chose the participants who really have experienced in using DGBL by read their background educations, our lecturer's relatives from the Academic Article Writing subject, and by asking some people. During the sessions, the participants freely say anything that would be much convinced while answering each question as the additional information to gain the data. So then, the collected data will be discussed further to analyse what are the categories of those answers related to in the finding and discussion part.
III. FINDINGS AND DISCUSSION

From all the data which already obtained, this study reveal some general themes for each topic as the results below.

\section{The implementation of Digital Game BASED LEARNING IN THE CLASSROOM (QUESTIONS 1-3)}

2. The teacher's preliminary experience in Digital Game Based Learning (questions 4-6)

3. The effectiveness of using Digital Game Based Learning (questions 7-10)

Then the researchers analysed the data that have collected during the research through face-to face interview by explain the result below. The explanation here based on the answer from all of the participants who have given the data for this research.

The first question, how is teachers' experiences in implementing DGBL in the EFL classroom have already answered. That is all of the participants have experiences in using digital game based in the classroom whether it's for doing testing, delivering material such as in grammar skill, concept check reading, listening skill, reading skill such as teaching genres text like descriptive text, introducing new games that related to educational field or even just to break the ice when teaching and learning process. There are many kinds of games that is used by teacher such as kahoot, hangman (hangout), crossword, socrative, quize makers, clickers, edpuzzle, township, second mark image annotation and many games from british council website. In selecting the game, each teacher also has their own consideration such as the games should be based on learning objective, students' level and students' interest, related to the materials that are going to be taught, culture suitability, and based on lesson plan that the teachers' made before they are teaching. In knowing the games, the English teachers also have their own way. There are some teachers who firstly know those kinds of games from searching on the internet, joining workshop, seminar, conference, also from their friend that have already applied some games in the class, and from MGMP where all of the teacher have gathering activity. There are several reason why the English teacher use a game in their teaching and learning process and one of them is because the use of digital game based gives so many advantages. The advantages are not only for the students but also for the teacher who introduce such kinds of game for students. The advantage for the teacher is like the teacher can develop their teaching by introducing and implementing several games and also digital game requires simple things to be implemented. And 
for the students, the advantages of games are starting from it's interesting to use the game in the teaching and learning process, the games also give instant feedback for the students, it can increase students", attention, networked, minimize paper based test, minimize the burden of the students, engage learners to teaching and learning environment, stimulate their cognitive, affective, and psycho motoric, less cheating for the students, triggering the brain and emotion to critically solve the problem and more helpful to other friend, students also can get new information and get different atmosphere in the class, and make fun situation in the teaching and learning process.

The second question, related to the teachers' challenge in implementing DGBL. So far the challenge is about internet connection, it's become a backstop for the teacher to apply digital game in the classroom. A bad internet connection in Indonesia make the teacher thinking twice to use digital game based in the class. The other challenges are about trial error at the first time, giving instruction or tutorial before the students playing the game in the class, and limited time in the class

The last is about third question, it's about the strategy in coping such challenges that might face by the teacher. Most of the teachers have the same opinion, that's to cope such challenges, the teachers should assure that there is a good internet connection provided, the teacher also need to provide the tutorial before they implement digital game based in the class so it is not wasting time, provide other alternative such as printing out the slide on the game so students just need to point out the truest answer, the teacher also need to manage the plan carefully, in university, the teacher should tell the students to bring their smartphone and a good internet connection so the activity will run well, and when trial error happen, the teacher need to look for what is the cause of this situation.

In the last, the result of this study show that most of English teachers that have interviewed like to use digital game based learning because it gives so many advantages for their students. But beside the advantages, digital game based also provide the challenge for each English teacher such as internet connection provided in Indonesia. So this kind of challenge also make the teacher thinking twice to use digital game based in their classroom.

\section{CONCLUSION}

The paper has presented the responses from the English teachers' from some institutions (school and university) in Indonesia. As what have been explained above, the most importantly, from a research perspective, this study reveals how teachers' voices are during the use of digital game based in English language teaching. Surprisingly, there are very few teachers which can successfully integrate digital games in the learning of English. It is important to amalgamate fun in the learning of English especially in EFL setting to garner pupils' interest and eagerness to learn English yet, the limited facilities provided by the school and the limited access of internet connection in Indonesia becomes the biggest problem that may disturb the use of digital game when teaching.

However, there are several strategies can be used by teachers to deal with such problems such as taking a more concern to plan the teaching learning using lesson plan, and having sudden wise decision to manage the class with the limited access of both internet and technology and certainly to make the atmosphere still fun with the use of digital game for English language teaching.

\section{REFERENCES}

[1] Aboud, S. J., \& AL-Fayoumi, M. A. (2014). An efficient Internet bingo scheme. International Journal, 4(1).

[2] ALYAZ, D., \& GENC, D. (2016, October). Digital GameBased Language Learning In Foreign Language Teacher Education. Turkish Online Journal of Distance EducationTOJDE, 17, 130-146.

[3] Chen, Y. (2017). Empirical Study on the Effect of Digital Game-Based Instruction on Students' Learning Motivation and Achievement. Eurasia Journal of Mathematics, Science and Technology Education, 13(7), 3177-3187. https://doi.org/10.12973/eurasia.2017.00711

[4] Erhel, S., \& Jamet, E. (2013). Digital game-based learning: Impact of instructions and feedback on motivation and learning effectiveness. Computers \& Education, 156-167.

[5] Gamlo, N. (2019). The Impact of Mobile Game-Based Language Learning Apps on EFL Learners' Motivation. English Language Teaching, 12, 49-56.

[6] Gutiérrez, R. C., \& López, J. M. (2016). Game-based learning and gamification in initial teacher training in the social sciences: an experiment with MinecraftEdu. International Journal of Educational Technology in Higher Education, 1-11.

[7] Huizenga, J., Admiraal, W., Akkerman, S., \& ten Dam, G. (2009). Mobile game-based learning in secondary education: engagement, motivation and learning in a mobile city game. Journal of Computer Assisted Learning, 1-13.

[8] Hava, K., \& Cakir, H. (2017, June). A systematic review of literature on students as educational computer game designers. In EdMedia+ Innovate Learning (pp. 407- 419). Association for the Advancement of Computing in Education (AACE).

[9] Kumar, R., \& Lightner, R. (2007). Games as an Interactive Classroom Technique: Perceptions of Corporate Trainers, College Instructors and Students. International Journal of Teaching and Learning in Higher Education, 19, 53-63.

[10] Mayer, R. E., \& Johnson, C. I. (2010). Adding instructional features that promote learning in a game-like environment. Journal of Educational Computing Research, 42(3), 241265. http://dx.doi.org/10.2190/EC.42.3.

[11] Plump, C. M., \& LaRosa, J. (2017). Using Kahoot! in the classroom to create engagement and active learning: A game-based technology solution for eLearning novices. Management Teaching Review, 2(2), 151-158.

[12] Setyaningrum, W., Pratama, L. D., \& Ali, M. B. (2018, September). Game-Based Learning in Problem Solving Method: The Effects on Students' Achievement. International Journal on Emerging Mathematics Education (IJEME), 2, 157-164. 


\section{PRESS}

[13] Shahriarpour, N., \& Kafi, Z. (2014). On the Effect of Playing Digital Games on Iranian Intermediate EFL Learners' Motivation toward Learning English Vocabularies. Procedia - Social and Behavioral Sciences, $1738-1743$.

[14] Whitton, N. (2009). Learning with digital games: A practical guide to engaging students in higher education. Routledge. 